What Is Talmud? 
This page intentionally left blank 


\section{What Is Talmud?}

THE ART OF DISAGREEMENT

Sergey Dolgopolski

FORDHAM UNIVERSITY PRESS

NEW YORK 2009 
Copyright (C) 2009 Fordham University Press

All rights reserved. No part of this publication may be reproduced, stored in a retrieval system, or transmitted in any form or by any means-electronic, mechanical, photocopy, recording, or any other-except for brief quotations in printed reviews, without the prior permission of the publisher.

Fordham University Press has no responsibility for the persistence or accuracy of URLs for external or third-party internet websites referred to in this publication and does not guarantee that any content on such websites is, or will remain, accurate or appropriate.

Library of Congress Cataloging-in-Publication Data

Dolgopol'skii, S. B. (Sergei Borisovich)

What is Talmud? : the art of disagreement / Sergey Dolgopolski. p. $\mathrm{cm}$.

Includes bibliographical references and index.

ISBN 978-0-8232-2934-5 (cloth : alk. paper)

1. Talmud-Methodology. 2. Talmud-Criticism, interpretation, etc. 3. Talmud-Philosophy. 4. Reasoning. 5. Rhetoric. I. Title. BM503.6.D65 2008

296.1'2506-dc22 2008043310

Printed in the United States of America

$111009 \quad 54321$

First edition 
To the blessed memory of my mother $z " l$, my most important teacher 
This page intentionally left blank 